\title{
THE INHERITANCE OF THE BLOOD GROUPS
}

\author{
LAURENCE H. SNYDER \\ North Carolina State College, Raleigh, North Carolina
}

Received April 26, 1924

TABLE OF CONTENTS

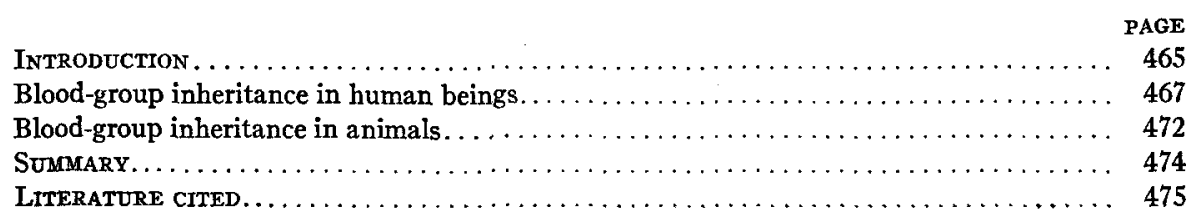

\section{INTRODUCTION}

Ever since their discovery in 1900 by LANDSTEINER (1900) and SHATTOCK (1900) working independently, great interest has been shown in the blood groups by medical men. Important research has been carried out on the inheritance of the groups and on their racial distribution, but scarcely more than a paper or two has reached beyond the medical literature. The problems involved are of interest to biologists in general, and to geneticists in particular, so that a summary of our present knowledge of the inheritance of the blood groups should be of value.

The first and most practical application of blood grouping was to the problem of blood transfusion. Prior to the knowledge of blood groups, serious and even fatal reactions often followed the transfusion of blood from one person to another. The knowledge that there were definite substances in the serum of some bloods that would agglutinate, or clump, the red cells of certain other bloods, made possible safe transfusion. By testing the bloods of donor and recipient, no reaction need occur, while in the absence of such tests, serious reactions might occur in approximately a third of the cases (Zimmerman 1920). For safe transfusion, it is only necessary that the serum of the recipient does not agglutinate the red cells of the donor. The principles of blood transfusion have been found to apply equally well to skin grafting (SHAWAN 1919).

At first agglutination was thought to occur only in diseased persons, but it soon became clear that the phenomenon was of general occurrence.

LANDSTEINER (1901) divided human blood into three groups on the basis of the agglutinating reactions. The next year Decastello and 
STURLI (1902) described a fourth group. In 1907 JANSKY proposed a definite classification of blood into four groups. Three years later, Moss (1910) in this country, proposed a classification, recognizing, as did JANSKy, four groups. The two classifications differ only in terminology, groups I and IV being interchanged. Both of these classifications were extensively used, causing much confusion and many serious consequences, with the result that a committee was appointed to consider the adoption of a uniform classification. The JANSKY classification, because of its priority, was adopted, and will be used throughout this discussion. The scheme of this grouping is given in table 1 .

TABLE 1

Scheme of the JANSKY (1907) classification of blood groups.

\begin{tabular}{c|l|l}
\hline \multirow{2}{*}{ GROUP } & EFFECT OF SER IM & \multicolumn{1}{|c}{ CAPACITY OF CELIS } \\
\hline I & Agglutinates cells of II, III, IV & Not agglutinated by any serum \\
II & Agglutinates cells of III and IV & Agglutinated by serum of I and III \\
III & Agglutinates cells of II and IV & Agglutinated by serum of I and II \\
IV & Does not agglutinate any cells & Agglutinated by serum of I, II, III \\
\hline
\end{tabular}

These four blood groups have now been shown to occur universally. They have been demonstrated in England (LEARMonTH 1920, Keynes 1921, Dyke 1922), Germany (von Dungern and Hirschfeld 1910), Hungary (VERZÀr 1921-1922), Italy (LATTEs 1923), Czechoslovakia (Weszeczky 1920), Norway (Jervell 1923), Denmark (Johannsen 1921), Europe in general, including Frenchmen, Bulgarians, Serbians, Greeks, Russians, and Turks (HirschFeld and Hirschfeld 1919), China (Liv and WANg 1920), Asia in general (HirschFeld and HirschFeld 1919), Africa (Hirschfeld and Hirschfeld 1919, Pirie 1921), Australia (TeBbut and McConnel 1922), the Philippine Islands (CABrera and WAdE 1921), the United States (Hektoen 1907, Moss 1910), and among the Icelanders (Jonsson 1923), the American Indians (CoCA and Diebert 1923) and the American negroes (Lewis and Henderson 1922). The anthropological importance of the distribution of the groups has been discussed by the HirschFeldos (1919), Lewis and Henderson (1922) and others.

GAY (1907) sought to explain the phenomenon of agglutination on a physico-chemical basis, as due to variations of molecular energy. But it soon became apparent that the clumping must be due to specific substances in the blood. Those in the serum, causing the clumping, were 
designated iso-agglutinins, while the receptors in the red cells were called agglutinogens.

To explain the facts of agglutination, Moss (1910) assumed the presence in the blood of three such agglutinins, and three agglutinogens. Other authors (LANDSTEINER 1901, von DUNGern and Hirschfeld 1910, SCHUTZE 1921) have postulated the presence of only two of each. The latter is the only possible interpretation which will fit all the known facts, as pointed out by UNGer (1921) and GICHNER (1922), and is the one generally accepted at present.

It is also clear from the investigations that the absence of either agglutinogen always coincides with the presence of the corresponding agglutinin. In other words, the agglutinating power of the serum of a blood and the agglutinophilic capacity of its red cells are reciprocal. Moreover, the specific agglutinogens never appear in the offspring unless they are present in the blood of one of the parents, but agglutinins may appear in the offspring, that are absent from the blood of both parents. These facts gave the clue to the possibility of the inheritance of the groups on the basis of two pairs of unit characters, the agglutinogens (now called $A$ and $B$ ) being dominant over their corresponding agglutinins ( $a$ and $b$ ).

Interest developed rapidly in the inheritance of the groups. As in most cases of human heredity, studies on the inheritance of blood groups have followed two main lines: first, the collection and interpretation of the available human data; and second, the attempt to learn the bloodgroup heredity in human beings by observing the behavior of the groups in other forms. The human data will be considered first.

\section{BLOOD-GROUP INHERITANCE IN HUMAN BEINGS}

OtTenberg and Epstein (1908) made the first suggestion that the blood groups might be inherited on a Mendelian basis. Von Dungern and HIRSCHFELD (1910), presented data on 72 families, comprising 348 individuals, in which the grouping of the blood had been tested in two generations. The results indicated a probable Mendelian inheritance. In 1916, BREM stated that he found the groups hereditary, and that they probably followed MENDEL's laws, but he presented no evidence to uphold his view.

No further work was done on the problem until 1920, when LEARMONTH published the results of a study of the blood-group inheritance in forty families in England. From the facts of agglutination as stated above, it was clear that the agglutinophilic capacity was dominant over the power to agglutinate. Proceeding on the assumption, then, that $a$ gives the

GrNetics 9: S 1924 
power to agglutinate $A$, and $b$ the power to agglutinate $B$, LEARMONTH (1920) analyzed his forty families, and found that the expectations on a Mendelian basis were fully realized. It is clear that the genetical formulae for the groups, on the JANSKY classification, would be as in table 2 .

TABLE 2

Genetic formulae of the four groups.

\begin{tabular}{c|c|c|c}
\hline $\mathrm{I}$ & $\mathrm{II}$ & $\mathrm{III}$ & $\mathrm{IV}$ \\
\hline \multirow{2}{*}{$a a b b$} & $A A b b$ & $a a B B$ & $A A B B$ \\
& $A a b b$ & $a a B b$ & $A a B B$ \\
& & $A A B b$ \\
& & $A a B b$ \\
\hline
\end{tabular}

Group IV, being the double dominant, could carry either agglutinin as a recessive. Group I, however, being the double recessive, could not transmit either agglutinogen, and would have to breed true. LEARMONTH's one exception to the Mendelian rule was found in this connection. Two parents of group I had a child in group II. LEARMONTH suggested illegitimacy as the explanation, and concluded that the groups were inherited as two pairs of Mendelian unit characters.

This conclusion gained ready acceptance among medical men, and received support from several investigators, notable among them OTTENBERG, who was the foremost exponent of the Mendelian inheritance of the blood groups in this country. But it was not destined to escape opposition and criticism, and in 1921-1923 a lively controversy was carried on, chiefly between Ottenberg (1921, 1922, 1923) and Buchanan (1922, $1923)$ as to the interpretation of the available data. Especially was the medico-legal application of the blood groups the center of a storm of discussion. OtTENBERg had claimed the possibility of using the blood groups in doubtful and disputed paternity cases, stating that knowing the groups of the children and of one parent, one could sometimes say what the other parent must be.

BUCHANAN strenuously objected to this, basing his objections mainly on several instances in which he found that parents, both of group I, had children of some other group. Should such instances become at all frequent, they might be cause for disturbance. Buchanan, however, showed such evident lack of knowledge of the fundamental principles of Mendelism, and of the Mendelian interpretation which had been given to the groups, that his objections do not assume a very serious aspect. 
The possibilities, where parents, both of group I, have children of some other group, are, as pointed out by Keynes (1921): (1) the observations are at fault; (2) the putative father is not the real father; (3) the Mendelian theory of inheritance is wrong. To these $I$ would add a fourth, the possibility of more than four groups in human blood. This possibility will be considered later. Krynes concluded that since the Mendelian theory of inheritance is so well established, and in general there is no reason for supposing that the observations are inaccurate, we are forced to the conclusion that in such a case the child is illegitimate. OtTEnBERG answers BUCHANAN by saying that there is no reason for doubting the theory of Mendelian inheritance, and it is unlikely that BucranaN should have met with so many illegitimacies, so that his wrong conclusions must rest on his own mistakes.

To the support of a strict Mendelian interpretation of the blood groups have come other investigators. JERVELL (1923) in Christiania stated that he found the blood groups of 136 individuals in two generations of 32 Norwegian families to conform in every respect to the Mendelian interpretation. He concluded that a medico-legal application was thus possible. Keynes (1921), in England, as before stated, upheld the Mendelian interpretation. He presented an exceptionally large pedigree: a family of fifty-nine persons in four generations, which bears out in every respect the results expected on a Mendelian basis. LatTes (1923), in Italy, confirmed the value of OTTENBERG's theory of medico-legal application. Weszeczky (1920) in Czechoslovakia, with families tested to the fourth generation, and TebBut and McConnel (1922), in Australia, presented evidence to confirm the Mendelian interpretation of the groups. GichNer (1922), in the United States, has pointed out BuchanaN's evident lack of grasp of the situation. The evidence is overwhelmingly in favor of a Mendelian interpretation. The only thing which may in the future indicate that the two points of view are not necessarily opposed is the recent claim that there really are more than two iso-agglutinins and two agglutinogens in human blood.

GuTHRIE and HuCK (1923) and HuCK and GuTHRIE (1924), present evidence to show that there are at least three iso-agglutinins and three agglutinogens in human blood, making twenty-seven biologically possible combinations. If the additional agglutinins are inherited in a manner similar to the others, eight groups would be formed. CoCA and KLEIN (1923) found a third pair of iso-agglutination elements, which may be identical with those of Guthrie and Huck. These, however, CocA and KLEIN showed not to be inherited as Mendelian allelomorphs. As yet 
the possibility of more than four groups is an open question, but the inheritance of the four known groups is definitely Mendelian.

The medico-legal application, the possibility of which was mentioned by earlier writers (VON DUNGern and Hirschfeld 1910, Giraud 1919, HIRSCHFELD and HIRSCHFELD 1919), but which was first clearly set forth by OtTenberg (1921), is briefly as follows. Knowing the groups of the children and of one parent, it is sometimes possible to state what the other parent must be. The instances in which this can be done are tabulated in table 3 . In other words, one can sometimes say that a child is not the offspring of certain parents; one can sometimes say that the child might be the offspring of certain parents; but one can never state that a child $i s$ the offspring of certain parents.

TABLE 3

Prediction of remaining parent groups. (After OTTENBERG).

\begin{tabular}{|c|c|c|}
\hline $\begin{array}{l}\text { KNOWN CHILDREN IN } \\
\text { GROUP }\end{array}$ & $\begin{array}{l}\text { ONE PARENT KNOWN } \\
\text { TO BE IN GROUP }\end{array}$ & $\begin{array}{l}\text { OTUER PARENT WI:N } \\
\text { BE IN GROCP }\end{array}$ \\
\hline $\begin{array}{l}\text { II } \\
\text { II }\end{array}$ & $\begin{array}{r}\text { I } \\
\text { III }\end{array}$ & $\begin{array}{l}\text { II or IV } \\
\text { II or IV }\end{array}$ \\
\hline III & $I$ & III or IV \\
\hline III & $\mathrm{II}$ & III or IV \\
\hline IV & I & IV \\
\hline IV & II & III or IV \\
\hline IV & III & II or IV \\
\hline II and III & I & IV \\
\hline II and III & II & III or IV \\
\hline II and III & III & II or IV \\
\hline II and IV & $I$ & IV \\
\hline II and IV & II & III or IV \\
\hline II and IV & III & II or IV \\
\hline III and IV & $I$ & IV \\
\hline III and IV & II & III or IV \\
\hline III and IV & III & II or IV \\
\hline
\end{tabular}

At various times it has been stated that the blood groups could be changed or modified by action of drugs or other agencies; a condition which might complicate the heredity of the groups; but the evidence now seems to show that the groups are remarkably stable. LEviNe and SEGALL (1922) reported that prolonged etherization might cause a tem- 
porary change in the iso-agglutination phenomena. They cited instances to uphold this statement. Huck and Peyton (1923) tried experiments to test this and concluded that there is no change in the blood groups after ether anesthesia.

VORSCHÜTZ (1922) presented evidence that the previous taking of a drug, or general anesthesia, or Roentgen irradiation might modify the blood enough to change it from one group to another for the time being. H.ARPER and BYron (1922) claimed that diet might influence agglutination. EDEN (1922) and Dremer (1922) found changes in the iso-agglutinins after the administration of various drugs (quinine, calcium lactate, antipyrin, arsenic, ether, chloroform), and after exposure to Roentgen rays. Meyer and Ziskoven (1923) tested these claims, and found no such changes. They attributed the earlier results to a mistake due to sedimentation of corpuscles. Mino (1923) states from experiments with numerous patients and various drugs that it is impossible to modify the iso-agglutinins and to change blood grouping.

Another interesting phase of the problem is the question of blood groups in the new-born. The earlier workers discovered that the agglutinophilic capacity of the blood was usually present at birth, but that the specific iso-agglutinins might not appear until later. ROBERTSON, Brown and Simpson (1921) confirmed these results experimentally, but stated that transfusion from mother to infant should not be made without first testing the compatibility of the blood. UNGER (1921) came to similar conclusions. HAPP (1920) found that both agglutinins and receptors might be absent at birth, but he also stated that compatibility tests should always be made. Cherry and Langrock (1916) failed to find any agglutination whatsoever between the blood of a mother and that of her new-born babe. Jones (1921) found that the receptors were always present at birth, and that in most cases the iso-agglutinins were also present. He demonstrated iso-agglutinins in the blood of a seven-months fetus.

MCQUARRIE (1922) tested the blood of 180 new-born infants against the blood of their respective mothers. In nearly half there was no evidence of iso-agglutinins in the serum, nor of receptors in the red cells, of the infant. In 23 percent of the cases, however, the mother's serum agglutinated her infant's cells. DE BIASI (1923) found that in no case was there any agglutination between the blood of a mother and that of her new-born infant, regardless of whether or not they belonged to incompatible groups: Moreover, the cells of the infant always contained their full complement of receptors, since they could be easily grouped by means of test sera: 
DE BIASI's work would indicate that although the receptors were present in the red cells of the infant, the agglutinins of its own mother had no effect on them, and that a mother could safely be used as donor for her new-born infant without compatibility tests, thus confirming CHERRY and LANGROCK's (1916) earlier work. The general opinion seems to be that the agglutinophilic capacity of the red cells is present at birth, although whether or not the cells in a new-born child can be agglutinated by the mother's serum is an open question. The specific iso-agglutinins may be delayed in their appearance for several months.

No definite physical characters of the blood are associated with the presence or absence of agglutinins, although ALEXANDER (1921), from a study of the blood groups of a number of cases, claimed that persons in groups I and III were peculiarly susceptible to malignant disease. BUCHANAN and HIGLY (1921), however, showed that no group was more susceptible than any other to disease. No human characters of any kind have been shown to be linked with the blood groups.

\section{BLOOD-GROUP INHERITANCE IN ANIMALS}

The other line of research on the inheritance of the groups, that of studying the behavior of the blood groups in animals, has not met with such success, chiefly due to the fact that no blood groups in animals have been clearly demonstrated.

VON DUNGERN (1910) sought to demonstrate by the absorption method that iso-agglutinins and agglutinogens were present in a variety of animals.

Hextoen (1907) made the first direct tests on animal blood. He used rabbits, guinea-pigs, dogs, horses and cattle. In no case did he find agglutination, although ten to twenty individuals of each species were used.

In 1911, OtTENBERG and FrIEDMAN studied rabbits and steers, and found that the bloods of thirty-two rabbits fell into four groups, while the bloods of eleven steers could be placed in three groups. To account for this, they assumed the presence in the blood of rabbits of two iso-agglutinins and two agglutinogens; in the blood of steers they assumed the presence of one of each.

INGEBRIGSTEN (1912 a, b) studied forty cats. In five cases he found inter-agglutination, but most instances showed no agglutination. $\mathrm{He}$ could not make a satisfactory grouping. In dogs he also failed to find iso-agglutinins.

In 1913, Fishbein studied several species, including 60 swine, 60 cattle, 40 sheep, 25 rabbits, 20 frogs and 10 dogs. He found only occasional agglutination. FISHBEIN concluded that iso-agglutination in animals 
is a much less pronounced phenomenon than in man, and that no satisfactory grouping could be consistently made in animals.

OTTENBERG, FRIEDMAN and KALISKY (1913) found occasional agglutination, but no sharp grouping, in dogs. In 1915, OtTenberg and ThalHIMER confirmed INGEBRIGSTEN's (1912 a, b) results that no grouping could be made in the blood of cats.

WESZECZKY (1920) found no agglutination in guinea-pigs, rabbits, cattle and chickens. In horses, swine and dogs he found occasional agglutination, but could make no grouping.

ROHDENBERG (1920) failed to find agglutination in fifty rats of different strains. MACDOWELL and HUBBARD (1922) did not find any agglutinins in mice, although ten widely different strains were used, involving 1180 combinations of serum and corpuscles.

Pannisset and Verge (1922) could not detect any evidence of fixed blood groups in either horses or cattle. Przesmycki (1923) using the method of iso-transfusion, failed to find any evidence of agglutination in rabbits. In horses, however, the results indicated two groups. WaLSH (1924) found irregular iso-hemagglutination in horses, but could not demonstrate any grouping.

The present writer (SNYDER 1924), studied rabbits for their iso-agglutinins. Practically every known variety of the domestic rabbit was used, the strains varying from the large Flemish Giant to the small Polish rabbit, and from stock which had been in American laboratories for generations to freshly imported animals. The rabbits were from Dr. CASTLE's stock at the Bussey Institution, and the testing was done at the MASSACHuSETtS ANTITOXIN aND Vaccine Laboratory. The technique was as follows: The rabbits were bled from the marginal ear vein. The skin over the vein was shaved and rubbed with xylol to induce hyperemia. A hot cloth was applied at the base of the ear. The blood was drawn through a 22-gauge needle into a 10 -cc syringe.

Three drops of blood were added to $10 \mathrm{cc}$ of sodium citrate solution (1-percent sodium citrate in isotonic salt solution). This gave a 2-percent suspension of blood without clotting. This suspension was centrifuged, and the supernatant fluid pipetted off. The original amount of solution was restored by adding isotonic salt solution.

The remaining portion of the blood taken from the rabbit was allowed to clot in a centrifuge tube. After an hour at room temperature, the clot was loosened. The tubes were allowed to stand overnight in the ice chest. The clot was then whirled down, and the serum was transferred 
to a sterile vial. Sterile apparatus and rigid aseptic technique were used throughout the tests.

The macroscopic method of reading was used. 'Two-tenths cc of serum were added to one-tenth $\mathrm{cc}$ of washed corpuscles in small vials. The vials were then placed in the incubator at $37^{\circ} \mathrm{C}$ for an hour, after which the first reading was made. The vials were then placed in the ice-chest, and several subsequent readings made at intervals of an hour, and again after the vials had stood over night in the ice chest.

Each serum was tested against as many other corpuscles as possible. Its own corpuscles acted as a control. Serum from each strain was tested against corpuscles from each of the other strains.

Microscopic observations of hanging drops were made with about 10 percent of the combinations to act as a check. In every case the microscopic observation confirmed the macroscopic reading.

About two thousand combinations of serum and corpuscles were made, but no evidence of iso-agglutinins could be detected.

With regard to the agglutination of the cells of one species by the serum of another, some interesting results have been obtained. It has long been known that in general there was agglutination between the bloods of different species of animals (PFEIfFer 1904). Human cells appear to be constantly agglutinated by animal serum (MARX and EHRNROOTH 1904, Williams and Patterson 1910, Kolmer and Matsumoto 1920, Kolmer and Trist 1920). Hooker and Anderson (1921) were able to produce specific agglutinating sera for the four groups of human cells by immunization of rabbits.

Although in general the bloods of different species agglutinate each other, MACDowell and HubBard (1922) found that rat serum did not agglutinate mouse cells. WEszEczKy (1920) found that the serum of the buffalo (presumably Bos bubalus) did not agglutinate the cells of cattle. WALSH (1924) found that horse serum did not agglutinate ass cells, although in most cases ass serum agglutinated horse cells. Mule serum did not agglutinate either horse or ass cells, nor were mule cells agglutinated by horse or ass serum. Results such as these may be of taxonomic importance, and should be carefully followed up. Likewise agglutination tests on monkeys and the anthropoid apes should be made.

\section{SUMMARY}

1. The four known blood groups in human beings appear to be inherited on the basis of two pairs of Mendelian unit factors, the specific agglutinogens being dominant to their respective iso-agglutinins. 
2. The recent claim that there are more than two iso-agglutinins and two agglutinogens in human blood, and therefore more groups, may in the future necessitate a modification of this scheme of inheritance.

3. On the basis of the facts known at present, a medico-legal application of the blood groups is possible.

4. The grouping can not easily be changed by the action of drugs, anesthesia, or Roentgen rays.

5. The agglutinogens are usually present at birth, but the specific iso-agglutinins may be delayed in their appearance for several months.

6. Blood groups are rare, if not entirely absent, in animals, and therefore no experimental method of studying their inheritance is readily available.

\section{LITERATURE CITED}

AIEXANDER, W., 1921 An inquiry into the distribution of the blood groups in patients suffering from malignant disease. British Jour. Exp, Path. 2: 66-70.

DE BIASI, B., 1923 Studies on iso-agglutinins in the blood of the new-born. Jour. Amer. Med. Assn. 81: 1776-1778.

BREM, W. V., 1916 Blood transfusion. Jour. Amer. Med. Asso. 67: 190-193

Bucranan, J. A., 1922 Medico-legal application of the blood group. Jour. Amer. Med. Assn. 78: 89-92, 79: 180-181.

$1923 \mathrm{~A}$ consideration of the various laws of heredity and their application to conditions in man. Amer. Jour. Med. Sci. 165: 675-708.

liuchanan, J. A., and Higley, E. T., 1921 The relationship of blood groups to disease. British Jour. Exp. Path. 2: 247-255.

Cabrera, C., and WADE, H. W., 1921 Iso-agglutination group percentages of Filipino bloods. Philippine Island Med. Assn. Jour. 1: 100-103.

ChERrY, T. H., and LANGROCK, E. G., 1916 The relation of hemolysis in the transfusion of babies with the mothers as donors. Jour. Amer. Med. Assn. 66: 626-627.

CocA, A. F., and Diebert, O., 1923 A study of the occurrence of the blood groups among the American Indians. Jour. Immun. 8: 487-493.

CocA, A. F., and KLEIv, H., 1923 A hitherto undescribed pair of iso-agglutination elements in human beings. Jour. Immun. 8: 477-487.

DeCAStello, A. and SturLI, A., 1902 Ueber die Isoagglutinine im Serum gesunder und kranker Menschen. Münchener med. Wochenschr. 49: 1090.

DrFmer, T., 1922 Weitere Untersuchungsergebnisse über willkürliche Beeinflussung der Hämagglutinationsgruppen. Mitth, a. d. grenzgeb. d. Med. u. Chir. 35: 464-476.

Douris, R., 1923 Application médico-légal des groups sanguins humains. Discussion de la paternité. Bull. d. Sc.; Pharmacol. 30 : 90-107.

DUNGERN, E. voN, and HIRSChFELD, D. L., 1910 a Ueber Vererbung gruppenspecifischer Strukturen des Blutes. Zeitschr. f. Immunitätsforsch. 6: 284-292.

$1910 \mathrm{~b}$ Ueber eine Methode das Blut verschiedener Menschen serologisch zu unterscheiden. Münchener med. Wochenschr. 57: 741

DYKE, S. C., 1922a On iso-hemagglutination. British Jour. Exp. Path. 3: 146-150.

$1922 \mathrm{~b}$ On the medico-legal importance of the blood groups. Lancet 2: 1271-1272.

DYre, S. C., and BUDGE, C. H., 1922-1923 On the inheritance of the specific iso-agglutinable substances of human red cells. Proc. Roy. Soc. Med. London 16: 35-43.

GeNETTCS 9: $\$ 1924$ 
EDEN, R., 1922 Die Bedeutung der gruppenweisen Hämagglutination für die freie Transplantation und über die Veränderung der Agglutinationsgruppen durch Medikamente, Narkose, Röntgenbestrahlung. Deutsche med. Wochenschr. 48: 85-86.

FishbeIn, M., 1913 Iso-agglutination in man and lower animals. Jour. Infect. Diseases 12: 133-139.

GAY, F. P., 1907 The function of tonicity in human isohaemagglutination. Jour. Med. Res. 17: 321-339.

Gichner, M. G., 1922 A biologic mechanism of human isohaemagglutination. Jour. Amer. Med. Assn. 79: 2143-2145.

Gtradd, G., 1919 Les groupes sanguins. Press méd. 1: 21-22

GuThris, C. G., and HUCK, J. G., 1923 On the existence of more than four iso-agglutinins in human blood. Johns Hopkins Hosp. Bull. 34: 37-49, 128-140.

HAPP, W. M., 1920 Appearance of iso-agglutinins in infants and children. Jour. Exp. Med. 31: 313-334.

HARper, J., and BYron, W. C., 1922 Influence of diet on blood grouping. Jour. Amer. Med. Assn. 79: 2222-2223.

HeKToEN, L., 1907 Iso-agglutination of human corpuscles. Jour. Infect. Dis. 4: 297-303.

Hirschfeld, H., and HirschFeld, L., 1919 Serologic differences between blood of different races. Lancet 2 (No. 5016): 675-678.

Hooker, S. B., and ANDerson, L. M., 1921 The specific antigenic properties of the four groups of human erythrocytes. Jour. Immun. 6: 419-444.

HuCK, J. G., and Gutrrie, C. G., 1924 Further studies on blood grouping. I. The antigenic properties of two types of group II erythrocytes. Johns Hopkins Hosp. Bull. 35: 23-27.

Huck, J. G., and Pexton, S. M., 1923 Study of iso-agglutination before and after ether anesthesia. Jour. Amer. Med. Assn. 80: 670-671.

INGEBRIGSTEN, R., 1912a Die Bedeutung der Iso-agglutinine für die Schicksale homoplastisch transplantierter Arterien. Münchener med. Wocherschr. 59: 1475.

1912b The influence of iso-agglutinins on the final results of homoplastic transplantation of arteries. Jour. Exp. Med. 16: 169-177.

JANSKY, JAN., 1907 Haematologické, studie u psychotiků. Sbornic Klinický 8: 85-139.

JERVELL, F., 1923 Om den retsmedicinske bedytning av de r $\phi$ de blodlegemers iso-agglutination hos mennesker. Norsk Magazin for Laegevidenskaben 84: 478-488.

Johannsen, E. W., 1921 Om Isoagglutininer i det menneskelige Blod. Hospitalstidende (Copenhagen) 64: 449-464.

Jones, B. B., 1921 Iso-agglutinins in the blood of the new-born. Amer. Jour. Dis. of Children 22: $586-597$.

Jonsson, St., 1923 Nogle Undersøgelser over Isoagglutininer hos Islaenders. Hospitalstidende 66: $45-52$.

KeYnes, G., 1921 Blood transfusion. Oxford Med. Publ. (London) p. 90.

Kolmer, J. A., and MAтsumoto, M., 1920 Natural antihuman hemolysins and hemagglutinins in horse serum in relation to serum therapy. Jour. Immun. 5: 75-88.

Kolmer, J. A., and Trist, M. E., 1920 Attempt to produce specific immune agglutinins and hemolysins for the four groups of human erythrocytes. Jour. Immun. 5 : 89-96.

LANDSTETNER, K., 1900 Zur Kentniss der antifermentativen lytischen und agglutinierenden Wirkungen das Blutserums.' Centralbl. für Bakt. 27: 361 .

LANDStenNer, K., 1901 Ueber Agglutinationerscheinungen normalen menschlichen Blutes. Wiener klin. Wochenschr. 14 : 1132-1134.

LATtes, L., 1923 La dimostrazione biologica della paternità. Riforma Medica 39: 169-172.

LEARMonTH, J. R., 1920 The inheritance of specific iso-agglutinins in human blood. Jour. Genetics 10: 141-149 
Levine, E. C., and Segali, H. Ni; 1922 Posttransfusion reactions; alterations in blood after ether anesthesia and after blood transfusion. Surg. Gynec. and Obstet. 35: 313-319.

Lewis, J. H., and Henderson, D. L., 1922 The racial distribution of iso-haemagglutination groups. Jour. Amer. Med. Assn. 79: 1422-1424.

LIU, J. H., and WANG, H. S., 1920 Iso-agglutination tests on one thousand Chinese bloods. Nation. Med. Jour. China 6:118-120.

MacDowei., E. C., and Hubbard, J. E., 1922 On the absence of iso-agglutinins in mice. Proc. Soc. Exp. Biol. and Med. 20: 93-95.

Mattaner, F., and Johnston, E., 1921 Agglutinative and hemolytic action of calf serum on sheep cells. Jour. Immun. 6: 263-271.

MaRx, H., and EHRxRoOTH, E., 1904 Eine einfache Methode zur forensischen Unterscheidung von Menschen und Saügetierblut. Münchener med. Wochenschr. 51 : 293, 696.

MCQuarrie, I., 1923 Iso-agglutination in new-born infants and their mothers. Johns Hopkins Hosp. Bull. 34: 51-60.

MEYER, K., and ZISKov:eN, H., 1923 Ueber die Konstanz der agglutinatorischen Bluttypen des Menschen und die praktische Bedeutung der Bluttypenbestimmung. Med. Klin. 19: 87-89.

Mıno, P., 1923 Ricerche sulla modificabilità dei gruppi sanguini: Riforma Medica 39: 75-78.

Moss, W. L., 1910 Studies on iso-agglutinins and iso-hemolysins. Johns Hopkins Hosp. Bull. 21: $63-70$.

OtTmNBerG, R., 1921, 1922 Medico-legal application of human blood grouping. Jour. Amer. Med. Assn. $77: 682-683 ; 78: 873-877$.

1921, 1923 Hereditary blood qualities. Jour. Immun. 6: 363-386; 8: 11-19.

Ottenberg, R., and EpsteiN, L., 1908 [Discussion.] Trans. New York Path. Soc. 8: 117.

Ottenberg, R., and Friedman, S. S., 1911 The occurrence of grouped iso-agglutination in the lower animals. Jour. Exp. Med. 13: 531-535.

OtTExberg, R., Friedman, S. S., and Kalisky, D. J., 1913 Experimental agglutinative and hemolytic transfusions. Jour. Med. Res. 28: 141-163.

OttenberG, R., and Thalmimer; W., 1915 Studies in experimental transfusion. Jour. Med. Res. 33: 213-229.

Pantsset, L., and Verge, J., 1922 Sur l'existence des groups sanguins chez les animaux. Compt. Rend. Soc. de Biol. 87: 870-872.

PFEurfer, H., 1904 Erfahrungen mit der Marx-Ehrnroothschen Methode zur forensischen Unterscheidung von Menschen- und Tierblut. Deutsche med. Wochenschr. 30: 10981100.

PIRIE, J. H., 1921 Blood testing preliminary to transfusion; with a note on the group distribution among South African natives. Med. Jour. South Africa 16: 109-125.

PRzesmycki, F, 1923 Researches on transfusion of blood in horses and rabbits. Exper. and Social Med. (Warsaw) 1: 2-3.

Robertson, B., Brown, A., and Stmpson, R., 1921 Blood transfusion in children. Northwest Med. 20: 233-243.

Rohdenberg, G. L., 1920 The iso-agglutinins and iso-hemolysins of the rat. Proc. Soc. Exp. Biol. and Med. 17: 82-83.

SснÜтzE, H., 1921 Haemagglutination and its medico-legal bearing; with observations upon the theory of iso-agglutinins. British Jour. Exp. Path. 2: 26-33.

Shatrock, S. G., 1900 Chromocyte clumping in acute pneumonia and certain other diseases, and the significance of the buffy coat in the shed blood. Jour. Path. and Bacteriol. 6: 303-314.

Srawan, H. K., 1919 The principles of blood grouping applied to skin grafting. Amer. Jour. Med. Sci. 157: 503-508.

SNYDER, L. H., 1924 Iso-haemagglutinins in rabbits. Jour. Immun. 9: 45-48. 
Tebeut, A. H., and McConnes, S., 1922 Human iso-hemagglutinins; their distribution among some Australian aborigines. Med. Jour. Australia 1: 201-2( 8

UNGER, L. J., 1921 Precautions necessary in the selection of a dcr.c.,$r$ blood transfusion Jour. Amer. Med. Assn. 76: 9-12.

VerzÁr, F., 1922 Neue Untersuchungen über iso-hämagglutinine. Klin. Wochenschr. 1: 929 931.

Verzár, F, and Weszkčkxy, O., 1921-1922 Rassenbiologische Untersuchungen mittels Isohämagglutininen. Biochem. Zeitschr. 126: 33-39.

VORSCHÜтz, J., 1922 Zur Frage der gruppenweisen Hämagglutination und über die Veränderungen der agglutinationsgruppen durch Medikamente, Narkose und Röntgenstrahlen. Zeitschr. f. klin. Med. 94: 459.

WALSH, L. S. N., 1924 a The blood interrelationship of horses, asses and mules. Jour. Inmun. 9: $49-55$,

1924b Hemagglutination in horses. Jour. Immun. 9: 57-73.

WEszECZKY, O., 1920 Untersuchungen über die gruppenweise Hümagglutination beim Menschen. Biochem. Zeitschr. 107: 159-171.

Williams, H. U., and Patterson, H. A., 1918 The agglutination of human red corpuscles by horse serum. Jour. Amer. Med. Assn. 70 : 1754-1755.

ZimMERMan, R., 1920 Untersuchungen über die Hạüfigkeit des Auftretens von Isoagglutininen und Isohemolysinen im Hinblick auf die Bluttransfusion. Zentralbl. f. Gynäk. 44: $1146-1151$. 